\title{
Attitudes of Undergraduates towards Grammar Translation Method and Communicative Language Teaching in EFL Context: A Case Study of SBK Women's University Quetta, Pakistan
}

\author{
Hina Durrani \\ SBKWomen's University Quetta, Pakistan \\ E-mail: hinadurrani111@yahoo.com
}

Doi:10.7575/aiac.alls.v.7n.4p.167

URL: http://dx.doi.org/10.7575/aiac.alls.v.7n.4p.167
Received: 10/04/2016

Accepted: 16/06/2016

\begin{abstract}
CLT and GTM have been popular and much practiced methodologies in classrooms worldwide in teaching English language. The purpose of the current research is to examine students' attitude towards Grammar Translation Method and CLT in Pakistan at graduate level. The data for the current study was collected through questionnaire from undergraduate students of Baluchistan, Pakistan. The questionnaire was adapted from the studies of Palacios (2006) and McClintock (2011). Theoretical framework of Richard and Rodger (2001) was used as a guide for the study. However the data was analyzed quantitatively in SPSS. The overall results show that the students had a positive attitude towards GTM and their attitude was less favorable towards CLT.
\end{abstract}

Keywords: CLT, GTM, Attitudes

\section{Introduction}

Since English has become a global language and also an official language of more than 100 countries including Pakistan. It has become important for almost every individual to learn the language. As the novelist Sidhwa (1996) writes: "English ... is no more monopoly of the British. We the ex-colonized have subjugated the language, beaten it on its head and made it ours." ( $\mathrm{p}$ 231). However it has become an important reason for trade, occupation, immigration, social network, and so on.

To learn a foreign language effectively there are several methods and techniques that a teacher applies and it is also observed that these methods are proportionate to the performance of the students. According to Savignon (2002) in learning a foreign/second language, the meaning should be focused than the form.

In Pakistan where English is taught as a second language, usually the instructors use just two language teaching approaches namely Communicative Language Teaching (CLT) and

Grammar Translation Method (GTM).However CLT and GTM both have different characteristics. It is as if the focus in CLT is on fluency and communication and developing skills through communicative competence, then the main focus in GTM is on accuracy in reading, especially grammar teaching and translation.

In CLT classes teachers are responsible to organize communicative activities. Furthermore learner's participation is also appreciated in CLT classes. Therefore student/teacher interaction may take place in the real world situation (LarsenFreeman, 2000).

In CLT classes learners not only negotiate with their group members but also they need to be monitored and adjust what is happening in their learning process as well as learning objectives (Richard \& Rodgers, 2001).

According to Hymes (1972), competence should be viewed as "the overall underlying knowledge and ability for language which the speaker-listener possesses" (p. 13). That is, the concept of communicative competence involves knowledge of the language and the ability to use the knowledge in context.

However the study is a comparative analysis of two popular methods used by most of English language teachers: the traditional Grammar Translation Method and Modern Communicative Language teaching Method particularly in Baluchistan. This research is essential for the teachers of English language in order to know that to what extent these approaches are different and which method is more appropriate.

\section{Literature Review}

Since the aim of the present research was to examine that if provided an EFL environment, what attitude student show towards GTM and CLT when this is the Pakistani context. The basic function of ESL environment in English language classroom is to provide environment that function on the belief that a learner learns better in society of target language. Hiep (2007) was of the opinion that ESL classroom should have what Holliday (1994, p. 54) says the "optimum interactional parameters" that helps learner develop best communicative skills by a meaningful interaction with each other which they can apply in their real life right away. 
Moreover, Ellis (1996) points about the teachers role in ESL setting, was quite natural when he said that teacher plays a role of a facilitator only as the learner who would get actual learning outside the classroom.

\subsection{Grammar Translation Method}

Grammar translation method (GTM) was used to teach Latin and Greek which were the classical languages so the method was recognized with the name of classical method (Chastain 1988). The foundation of this method called GTM was an effort to teach grammar and translation and achieve the objective of languages so that the learners gain some knowledge about foreign languages after studying a number of grammatical rules. The learner applies the knowledge and the text is interpreted easily. GTM was followed by a concept that the grammar of target language can be helpful for the students and they can learn their native language well, similarly this grammar can help them speak and write better in their native language (Larsen- Freeman, Diane). Grammar translation method (GTM) is a very traditional and classic method in Pakistan where most of the schools and colleges apply this method. Teacher is a main source of communication in a classroom. All the activities and classroom tasks are given by teacher to the students are just to learn them to give examinations. (Larsen-Freeman, 2000).

The Purpose of using Grammar Translation method to teach was to pass their standardized exam after the preparation of reading and writing of only classical materials (Howatt, 1984; Rivers, 1981).

GTM method was especially designed to develop students mental capability to understand long classic and translate them, therefore fulfilled the purpose of Latin and Greek courses. "It was observed that if Latin is taught as a classical text, grammar was different and was even different if Latin was used as a lingua franca" (Celce-Murcia, 2014, p. 4)

It was stated that almost every textbook with grammar translation begins with the vocabulary list which may be bilingual and help the teachers teach basic grammar rules to students that would help them translate the sentences (Richards \& Rogers, 2001, p.4).

Chellapan (1982, p.60) points out: it is translation that enable students have a close grip in the target language. The students get clear with the perception of divergence and convergence by the concurrent awareness of media. As a result they get a divergent thinking by making themselves clear with the tools to perceive and analyze.

Alan Duff (1996) suggested that translation is a natural and essential process. He was of point that it is the translation that helps us shape our thinking to use the foreign language. He says that it is an impact of translation that one can understand how one language influence the other and also point out those habits that remain unnoticed to correct errors.

\subsection{Communicative Language Teaching}

The need for CLT was observed, when a need for a change in language teaching was felt (Richards \& Rodgers, 1986). Wilkins's (1976) found that CLT which is the notional syllabus has a great impact on the development. This impact was maintaining as a function of notional syllabus and includes communicational needs of a learner, Wilkins (1976). he defined notion as the concepts of location, sequence, frequency, quantity and time, and defined communicative functions as the language functions for example offers, requests, complaint, and denials (Wilkins, 1981). The notional syllabus and a communication language syllabus was designed which based on situations, language activities, language functions, notions. As a consequence, learner-centered and communication-oriented syllabus got its form (Richards \& Rodgers, 1986).

CLT classes require the use of accurate and fluent English while teaching. However, speaking a fluent language sometimes lack communication clearly (Brown, 2007). Errors do not matter a lot in activities based on fluency considering them tolerable and natural (Larsen-Freeman, 2000).

The study by Ming Chang (2011) reveals that the teachers' attitudes reveal their thinking in implementation of CLT in a language room. The study was conducted keeping teachers attitude in mind in Taiwan. The college teachers however showed favorable attitude towards CLT. The characteristics and principle of CLT were also displayed by the teacher's beliefs. These results also indicated that current beliefs of Taiwani teachers could have a meaningful and effective change in language teaching.

\subsection{Significance of Study}

- The study would draw an attention of the authorities of University to train their teachers to teach in CLT or GTM.

- Finding of this study would be a contribution to existing literature on CLT and GTM.

- Finally the current study will be helpful for the research scholars of Pakistan who are already working on GTM and CLT.

\subsection{Objectives}

This study will achieve the following objective:

To determine the attitudes of undergraduates of SBK Women's University towards GTM and CLT in EFL context?

\subsection{Research Questions}

What are the attitudes of undergraduates of SBK Women's University towards GTM and CLT in EFL context? 
Since the objectives of this study, cited above, are of quantitative in nature, this study employed quantitative method. The said method fulfills the purpose of measuring concepts or variables that are predetermined objectively and examined the relationship between them numerically and statistically. Creswell (2002) asserted that quantitative method paves a way for researchers to collect enriched data and its findings can also be generalized extensively.

\subsection{Sampling Technique}

The target population for the study was undergraduate Students of Baluchistan, Pakistan. A representative sample from the two academic major's i-e arts and science was randomly selected. There were 150 female participants. It was also considered that the participants were exposed to English for at least ten years in their educational career. All these students were 18-22 years in age.

\subsection{Data Collection Instrument}

The proposed study was quantitative in nature. The quantitative data was collected through questionnaires. The questionnaire was adapted from the studies of Palacios (2006) and McClintock (2011). There were 21 questions all together. The questionnaire was based on five points Likert Scale.

\subsection{Data Analysis Method}

In order to answer the research question, "What are the attitudes of undergraduates of SBK Women's University towards GTM and CLT in EFL context?” descriptive statistics was performed using SPSS (registered version 20.00) in which percentages and frequencies were calculated on the responses of the research participants.

\section{Results}

The present research was aimed to assess female students' attitudes of SBKWU towards the CLT and grammar translation approach in Quetta, Baluchistan, Pakistan. Study results for students are presented below. There were 150 students who participated in the study: all participants were female.

Table 1. Percentages of student's attitude about GTM

\begin{tabular}{|c|c|c|c|c|c|c|}
\hline No & Item & SD & $\mathrm{D}$ & $\mathrm{N}$ & A & SA \\
\hline 1 & $\begin{array}{l}\text { Grammar plays an important role in the study of } \\
\text { English. }\end{array}$ & & & $1.3 \%$ & $22.7 \%$ & $76.0 \%$ \\
\hline 2 & $\begin{array}{l}\text { The knowledge of grammar is indispensable for a } \\
\text { correct use of the language. }\end{array}$ & $49.3 \%$ & $34.0 \%$ & $6.7 \%$ & $4.0 \%$ & $6.0 \%$ \\
\hline 3 & $\begin{array}{l}\text { It is possible to speak English well without any } \\
\text { grammatical Knowledge. }\end{array}$ & $20.0 \%$ & $44.7 \%$ & $16.0 \%$ & $16.0 \%$ & $3.3 \%$ \\
\hline 4 & $\begin{array}{l}\text { It is possible to write English well without any } \\
\text { grammatical Knowledge. }\end{array}$ & $38.7 \%$ & 50.7 & $4.7 \%$ & $5.3 \%$ & $0.7 \%$ \\
\hline 5 & $\begin{array}{l}\text { Teacher's explanations are in general useful for } \\
\text { the study of grammar. }\end{array}$ & $3.3 \%$ & $4.0 \%$ & $6.0 \%$ & $62.7 \%$ & $24.0 \%$ \\
\hline 6 & The teaching of grammar must be done implicitly. & $12.7 \%$ & $34.0 \%$ & $9.3 \%$ & $32.0 \%$ & $12.0 \%$ \\
\hline 7 & $\begin{array}{l}\text { Syntactic analysis of phrases and sentences helps } \\
\text { immensely to better understand English grammar. }\end{array}$ & $0.7 \%$ & $0.7 \%$ & $2.0 \%$ & $67.3 \%$ & $29.3 \%$ \\
\hline 8 & $\begin{array}{l}\text { Contrastive analysis of English with Urdu is useful } \\
\text { in the study English grammar }\end{array}$ & $2.7 \%$ & $9.3 \%$ & $22.0 \%$ & $48.0 \%$ & $18.0 \%$ \\
\hline 9 & $\begin{array}{l}\text { Contextualized grammar practice is relevant in the } \\
\text { learning of English grammar. }\end{array}$ & $0.7 \%$ & $2.7 \%$ & $12.7 \%$ & $64.7 \%$ & $19.3 \%$ \\
\hline 10 & $\begin{array}{l}\text { Rules are important in the study of English } \\
\text { grammar. }\end{array}$ & $1.3 \%$ & $1.3 \%$ & $7.3 \%$ & $38.7 \%$ & $51.3 \%$ \\
\hline
\end{tabular}

Percentage of Participants' Response towards the GTM ( $\mathrm{N}=150)$ is calculated from table: 1.

1. In response of the question "Grammar plays an important role in the study of English." $76.0 \%$ respondents who were the majority strongly agreed and think that grammar is really important in study of English

2. In response of the question "The knowledge of grammar is indispensable for a correct use of the language." $49.3 \%$ respondents who were in majority strongly agreed with the statement and think that it is important to know grammar to learn correct language.

3. The response of question "It is possible to speak English well without any grammatical Knowledge." $44.7 \%$ participants disagreed with the question saying that this impossible to speak English without the knowledge of grammar. 
4. In answer of the question "It is possible to write English well without any grammatical Knowledge." 50.7\% respondents who were in majority, disagreed with the statement that Students can write English without learning grammar.

5. In answer of the cloze ended question "Teacher's explanations are in general useful for the study of grammar." majority of $62.7 \%$ participants agreed with the statement that teacher's explanation is helpful for student's learning.

6. In response of the question "The teaching of grammar must be done implicitly." majority of $34.0 \%$ respondents disagreed that grammar should be taught indirectly.

7. In answer of the question "Syntactic analysis of phrases and sentences helps immensely to better understand English grammar." majority of $67.3 \%$ respondents agreed with the statement that the grammar of words is important for understanding English.

8. In answer of the question which was pre structured "Contrastive analysis of English with Urdu is useful in the study of grammar." majority of $48.0 \%$ students agreed that contrastive analysis of English with Urdu is helpful for learning grammar.

9. In response of the structured question "Contextualized grammar practice is relevant in the learning of English grammar." $64.7 \%$ respondents that was the majority agreed that contextualizing grammar practice is helpful in learning of English.

10. In answer of the pre structured question "Rules are important in the study of English grammar." majority of $51.3 \%$ students strongly agreed that grammar rules are important in study of English.

Similarly the results of student's attitude towards CLT are calculated and tabulated in the following table.

Table 2. Percentages of student's attitude about CLT

\begin{tabular}{|c|c|c|c|c|c|c|}
\hline No & Item & SD & D & $\mathrm{N}$ & A & SA \\
\hline 1 & $\begin{array}{l}\text { Those activities in which one discovers } \\
\text { grammatical phenomena are truly effective. }\end{array}$ & $0.7 \%$ & $2.7 \%$ & $16.0 \%$ & $44.0 \%$ & $36.7 \%$ \\
\hline 2 & $\begin{array}{l}\text { Practical exercises are important in the study of } \\
\text { English grammar }\end{array}$ & $0.7 \%$ & $4.7 \%$ & $5.3 \%$ & $36.7 \%$ & $52.7 \%$ \\
\hline 3 & $\begin{array}{l}\text { The study of terminology is important in learning } \\
\text { of English grammar. }\end{array}$ & $0.7 \%$ & $6.0 \%$ & $18.0 \%$ & $54.7 \%$ & $20.7 \%$ \\
\hline 4 & $\begin{array}{l}\text { Reading bibliography about English grammar } \\
\text { helps Immensely in understanding it. }\end{array}$ & $2.0 \%$ & $9.3 \%$ & $29.3 \%$ & $43.3 \%$ & $16.0 \%$ \\
\hline 5 & $\begin{array}{l}\text { An English teacher should base at least some part } \\
\text { of students' grades on completing the assigned } \\
\text { group tasks. }\end{array}$ & $2.0 \%$ & $7.3 \%$ & $15.3 \%$ & $46.0 \%$ & $29.3 \%$ \\
\hline 6 & $\begin{array}{l}\text { An English teacher should require students to use } \\
\text { the language outside of class with other speakers } \\
\text { of the language (e.g. Internet, email, clubs, } \\
\text { community events, etc.). }\end{array}$ & $0.7 \%$ & $4.0 \%$ & $4.0 \%$ & $44.7 \%$ & $46.7 \%$ \\
\hline 7 & $\begin{array}{l}\text { An English teacher should teach the language } \\
\text { primarily by having students complete specific } \\
\text { tasks (e.g., finding out prices of rooms and rates at } \\
\text { a hotel) rather than grammar-focused exercises. }\end{array}$ & $4.0 \%$ & $10.7 \%$ & $12.0 \%$ & $42.7 \%$ & $30.7 \%$ \\
\hline 8 & $\begin{array}{l}\text { An English teacher should have students respond } \\
\text { to commands physically in the foreign language } \\
\text { (e.g., "stand up," pick up your book,"etc.)... }\end{array}$ & $4.0 \%$ & $4.0 \%$ & $10.0 \%$ & $43.3 \%$ & $38.7 \%$ \\
\hline 9 & $\begin{array}{l}\text { An English teacher should not use predominantly } \\
\text { small groups or pair work to complete activities in } \\
\text { class. }\end{array}$ & $11.3 \%$ & $30.7 \%$ & $30.0 \%$ & $20.0 \%$ & $8.0 \%$ \\
\hline 10 & $\begin{array}{l}\text { An English teacher should base at least some part } \\
\text { of student's grades on their ability to interact with } \\
\text { classmates successfully in the foreign language. }\end{array}$ & $0.7 \%$ & $5.3 \%$ & $12.7 \%$ & $51.3 \%$ & $30.0 \%$ \\
\hline 11 & $\begin{array}{l}\text { An English teacher should use activities where } \\
\text { students have to find out unknown information } \\
\text { from classmates using the foreign language. }\end{array}$ & $3.3 \%$ & $4.7 \%$ & $17.3 \%$ & $46.7 \%$ & $28.0 \%$ \\
\hline
\end{tabular}


In answer of the question "Those activities in which one discovers grammatical phenomena are truly effective." $44.0 \%$ participants agreed with the statement and think that activities discovering grammatical phenomena are effective.

12. In answer of the pre structured question "Practical exercises are important in the study of English grammar" $52.7 \%$ respondents who were in majority agreed with the statement and the usefulness of practical exercises.

13. In the response of the structured question "The study of terminology is important in learning of English grammar." most of $54.7 \%$ students agreed with the statement that the study of terminology is important in learning English.

14. in the findings of the structured question "Reading bibliography about English grammar helps immensely in understanding it." $43.3 \%$ of the responses were in agreement with the statement that bibliography helps students understand English grammar.

15. In the response of the structured question "An English teacher should base at least some part of students' grades on completing the assigned group tasks." majority of $46.0 \%$ respondents agreed saying that some grading should base on completing assigned grouped task.

16. In answer of the given question "An English teacher should require students to use the language outside of class with other speakers of the language (e.g. Internet, email, clubs, community events, etc.)." $46.7 \%$ of the majority respondents strongly agreed with the statement that students should be allowed to speak English outside the class with other speakers.

17. In answer of the given question "An English teacher should teach the language primarily by having students complete specific tasks (e.g., finding out prices of rooms and rates at a hotel) rather than grammar-focused exercises." majority of $42.7 \%$ students agreed with the statement that teachers should teach language by giving specific task to the students rather than grammar focused exercise.

18. In the response of the question "An English teacher should have students respond to commands physically in the foreign language (e.g., "stand up," pick up your book,"etc.)..." majority of $43.3 \%$ participants agreed that the physical commands should be given in foreign language.

19. In answer of the question "An English teacher should not use predominantly small groups or pair work to complete activities in class." majority of $30.7 \%$ respondents disagreed with the statement that teachers should not use small groups to complete activities in class.

20. In the findings of structured question "An English teacher should base at least some part of student's grades on their ability to interact with classmates successfully in the foreign language." $51.3 \%$ respondents who were the majority agreed that the class interaction should be graded.

21. In the response of the structured question "An English teacher should use activities where students have to find out unknown information from classmates using the foreign language." majority of $46.7 \%$ participants agreed that unknown information must be found out by the students by using specific activities

\section{Findings and Conclusions}

The basic purpose of the present research was to assess the attitudes of undergraduate female students of SBKWU towards CLT and grammar translation in Quetta, Baluchistan, Pakistan. The mode of instruction in this institute is GTM as well as CLT. According to Celce-Murcia (2014), in the grammar translation approach the target language is slightly used in communication (p.5),

This study measured the attitude of students' towards CLT and grammar translation. Overall, the results of this study showed the students positive attitudes towards both GTM and CLT. The majority of students had positive attitudes towards GTM; for example, 76\% students believed that the grammar plays an important role in the study of English.62.7\% students believed that the teachers explanation is useful for the study of grammar.

However the study measured student's attitudes towards CLT and Grammar Translation method. Overall, the results of this study showed that student's response towards GTM was positive and was less favorable towards CLT.

However the results of the study seem to match the results of Shamim (1996) who found that postgraduate students enrolled in linguistics and language teaching course in Pakistan resisted CLT. She found that the students were inclined towards traditional approaches of teaching and learning. Similarly the results of this study also show that the students were more inclined towards Grammar Translation Method.

\section{References}

Brown, H. D. (2007). Principles of language learning and teaching. New York: Pearson Education, Inc.

Celce-Murcia, M. (2014). An overview of language teaching methods and approaches. In M. Celce-Murcia, D. M. Brinton, \& M. A. Snow (Eds.), Teaching English as asecond or foreign language (4th ed., pp. 2-14). Boston, MA: Heinle Cengage Learning.

Chang, M. (2011, July). EFL Teachers' Attitudes toward Communicative Language Teaching in Taiwanese College.

Chellapan, K. (1982). Translanguage, Translation and Second Language Acquisition. In F Eppert (Ed.), Papers on translation: Aspects, Concepts, Implications (pp. 57-63) Singapore: SEMEO Regional Language Center.

Creswell, J. W. (2002). Educational research: Planning, conducting, and evaluating quantitative. Sage Publication 
Duff, A. (1996). Translation (5th ed.) . Oxford: Ox- ford University Press.

Ellis, G. (1996). How culturally appropriate is the communicative approach? ELT Journal, 50(3), 213-218.

Hiep, P. H. (2007). Communicative language teaching; unity within diversity. ELT Journal, 61(3), 193-201.

Holliday, A. (1994). The house of TESEP and the communicative approach: the special needs of state English language education. ELT Journal, 48(1), 3-11.

Howatt, A. P. R. (1984). A History of English Language Teaching. Oxford: Oxford University Press.

Hymes , D. H. (1972). On communicative competence. In C. J. Brumfit\&K. Johnson (Eds.), The communicative approach to languageteaching (2nd ed., pp. 5-27). Oxford: Oxford University Press

Hymes , D. H. (1972). On communicative competence. In C. J. Brumfit\&K. Johnson (Eds.), The communicative approach to languageteaching (2nd ed., pp. 5-27). Oxford: Oxford University Press.

Larsen-Freeman, D.2000 Techniques and Principles in Language Teaching (2nd ed.).Oxford, UK: Oxford University Press

McClintock, K. (2011). Korean university students' perceptions of communicative language teaching.TESOL Review, p. 145-58. Retrieved from: http://www.tesolreview.org/down/Kathryn.pdf on 15/05/2014

Richards, J. C., Rodgers, T. S.2001 Approaches and methods in language teaching(2nd ed.). Cambridge: Cambridge University Press.

Richards, J. C., \& Rodgers, T. S. (1986). Approaches and methods in language teaching. Cambridge:Cambridge University Press.

Sidhwa, B. (1996). South Asian English: Structure, use and users. In Kirkpatrick, Andy (2007), World Englishes: Implications for International Communication and English Language Teaching(pp, 96) Cambridge University Press.

Savignon, S. J. (1972). Communicative Competence: An Experiment in Foreign Language Teaching. Philadelphia: The Centre for Curriculum Development, Inc.

Wilkins, D. A. (1976). Notional syllabus. Oxford: Oxford University Press.

Wilkins, D. A. (1981). Notional syllabuses and the concept of a minimum adequate grammar. In C. J. Brumfit \& K. Johnson (Eds.), The communicative approach to language teaching (2nd ed., pp. 91-98). Oxford: Oxford University Press. 